If you do not need this publication after it has served your purpose, please return it to the Geological Survey, using the official mailing label at the end

UNITED STATES DEPARTMENT OF THE INTERIOR

OLIGOCENE FORAMINIFERA NEAR MILLRY, ALABAMA

PREPARED IN COOPERATION WITH THE ALABAMA GEOLOGICAL SURVEY

GEOLOGICAL SURVEY PROFESSIONAL PAPER 197-B 

UNITED STATES DEPARTMENT OF THE INTERIOR

Harold L. Ickes, Secretary

GEOLOGICAL SURVEY

W. C. Mendenhall, Director

Professional Paper 197-B

\section{OLIGOCENE FORAMINIFERA NEAR MILLRY, ALABAMA}

BY

JOSEPH A. CUSHMAN AND WINNIE MGGLAMERY

Prepared in cooperation with the ALABAMA GEOLOGICAL SURVEY

Shorter contributions to general geology, 1941

(Pages 65-84)

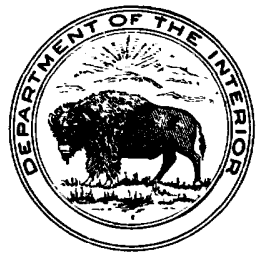

UNITED STATES

GOVERNMENT PRINTING OFFICE

WASHINGTON : 1942

For sale by the Superintendent of Documents, Washington, D. C. . . . . Price 10 cents 


\section{CONTENTS}

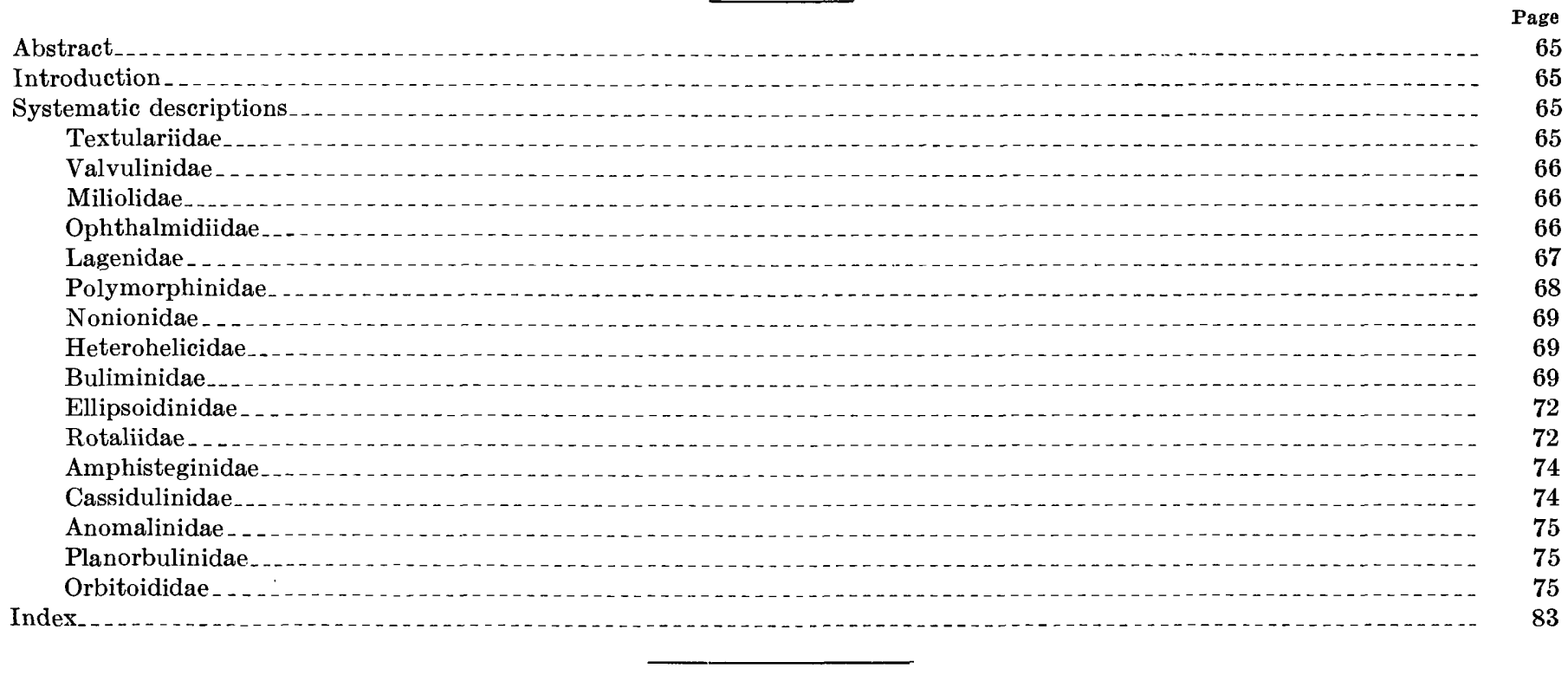

\section{ILLUSTRATIONS}

Prate 4. Miliolidae, Ophthalmidiidae, Lagenidae, and Polymorphinidae

5. Polymorphinidae, Nonionidae, Heterohelicidae, and Buliminidae

6. Buliminidae, Ellipsoidinidae, and Rotaliidae

7. Rotaliidae, Amphisteginidae, Cassidulinidae, Anomalinidae, and Planorbulinidae. 


\title{
OLIGOCENE FORAMINIFERA NEAR MILLRY, ALABAMA
}

\author{
By Joseph A. Cushman and Winnie McGlamery
}

\begin{abstract}
ABSTRAC' $\boldsymbol{T}$
This paper records an Oligocene foraminiferal fauna from the Chickasawhay marl at a locality near Millry, Ala. Approximately 42 genera are present, including 71 species and varieties. Ten species are identified only as to genus. The fauna is similar to that found at Choctaw Bluff, Ala.
\end{abstract}

\section{INTRODUCTION}

Collections, especially for Foraminifera, were made in the spring of 1937 from a limestone exposure 1.4 miles north of Millry, Washington County, Ala. These collections have been studied, and the results are presented here with illustrations of many of the species found.

The locality is in a road cut of State Highway No. 29, in sec. 17, T. 8 N., R. 3 W., where the following sequence is displayed:

\section{Section 1.4 miles north of Millry, Ala.}

Pliocene:

Red sandy clay

Ft. in.

Oligocene (Chickasawhay marl):

1. Greenish-gray, sandy, fossiliferous clay _..... 1

2. Hard cream-colored sandy limestone

3. Greenish-gray tossiliferous clay with lime nodules. . . . . . . . . . . . . .

4. Hard cream-colored very fossiliferous sandy limestone containing Bryozoa, Lepidocyclina sp., and fragments of Pecten sp........-.

5. Greenish-gray fossiliferous sandy clay with Bryozoa, Lepidocyclina sp., and barnacle

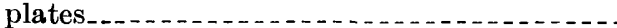

6. Hard cream-colored limestone in road ditch, with scattered glauconite and Lepidocyclina cf. L. undosa

1

3

$6-8$

2

1

In 1926 the exposure was referred by Cooke ${ }^{1}$ with doubt to the Byram marl. Howe and Alexander ${ }^{2}$ in 1934 placed it in the lower Chickasawhay member of the Catahoula sandstone. In a later paper (1935), Cooke ${ }^{3}$ refers this limestone to the Chickasawhay marl member of the Byram. The Chickasawhay marl is now classified as an independent formation.

The only well-preserved large fossils in our collection

1 Cooke, C. W., Geology of Alabama; The Cenozoic formations: Alabama Geol. Survey Spec. Rept. 14, p. 287, 1926.

2 Howe, H. V., and Alexander, C. E., Guidebook of the eleventh annual field trip of the Shreveport Geological Society into southeast Mississippi, p. 17, 1934.

${ }^{3}$ Cooke, C. W., Notes on the Vicksburg group: Am. Assoc. Petroleum Geologists Bull., vol. 19, p. 1169, 1935. from the locality are specimens of Ostrea vicksburgersis Conrad, taken from a railroad cut of the Tennessee \& Northern Railway, which parallels the highway. The limestone is extremely fossiliferous, especially in the lower portion, but the state of preservation is too poor for identification of most of the macrofossils.

The foraminiferal fauna contains numerous species already recorded from the Choctaw Bluff locality previously described by us. ${ }^{4}$ A number of new species from the present locality have been described e] $\mathrm{s}$ where ${ }^{5}$ so that they might be available to workers pending the publication of this paper.

Several species are not well enough preserved to give full specific characters. These are referred to under their generic names and figured for future referense, as more work in this area may result in the finding of complete and more abundant specimens.

Most of the species are identical with or clos $9 l y$ related to those known from the Oligocene Byram marl, and it is probable that these beds are of Oligocene age. As is usual, the softer clays yield a much richer fauna than the limestone, probably owing to the mechaniral difficulties of breaking down and washing the harder material of the limestone.

\section{SYSTEMATIC DESCRIPTIONS}

\section{Family TEXTULARIIDAE}

Genus TEXTULARIa Defrance, 1824

\section{Textularia tumidula Cushman}

Textularia tumidulum Cushman, U. S. Geol. Survey Prof. Paper 129-F, p. 125, 1922.

Cushman, U. S. Geol. Survey Prof. Paper 133, p. 15, $1 \subseteq 23$.

Ellisor, Am. Assoc. Petroleum Geologists Bull., vol. 17, pl. 1, fig. 3, 1933.

Fragmentary specimens in the material from beds 2 and 4 are sufficiently complete to make their identification definite and to place them in this characteristic Oligocene species. It has previously been recorded from the Vicksburg of Mississippi and Texas.

${ }^{4}$ Cushman, J. A., and McGlamery, Winnie, Oligocene Foraminifera from Choctaw Bluff, Ala.: U. S. Geol. Survay Prof. Paper 189-D, 1938.

5 Cushman, J. A., and McGlamery, Winnie, New Species of Foraminifera from the lower Oligocene of Alabama: Cushman Lab. Foram. Research Contr., vol. 15, pp. $45-49$, pl. 9 , figs. $1-8,1939$. 
Textularia mississippiensis Cushman var. alabamensis Cushman

Textularia mississippiensis Cushman var. alabamensis Cushman, U. S. Geol. Survey Prof. Paper 133, p. 17, pl. 1, fig. 4, 1923.

Howe, Jour. Paleontology, vol. 2, p. 175, 1928.

Ellisor, Am. Assoc. Petroleum Geologists Bull., vol. 17, pl. 1, fig. 6, 1933.

Cushman, U. S. Geol. Survey Prof. Paper 181, p. 7, pl. 1, figs. 5, 6, 1935 .

Palmer and Bermudez, Soc. cubana historia nat. Mem., vol. 10 , p. 241,1936 .

Very rare and rather poor specimens from bed 3 seem to belong to this variety, which is known from the Oligocene of Mississippi, Alabama, and Cuba and from the upper Eocene of Georgia, Alabama, South Carolina, Mississippi, and Texas.

\section{Family VALVULINIDAE}

\section{Genus CLAvUliNa D'Orbigny, 1826}

\section{Clavulina cf. C. tricarinata D'Orbigny}

In our previous paper on the Oligocene Foraminifera from Choctaw Bluff (U. S. Geol. Survey Prof. Paper 189-D, p. 104, pl. 24, fig. 3, 1938) a number of specimens were recorded and figured from the Oligocene. Very similar specimens, although less well preserved, occur in our present material, thus confirming the existence of this genus in the Oligocene of the Gulf Coastal Plain. The fragments occur in beds 2,4 , and 6 , showing that they were persistent during the deposition although represented by a single fragmentary specimen in each bed.

\section{Family MILIOLIDAE}

\section{Genus QUINQUELOCULINA D'Orbigny, 1826}

Quinqueloculina tessellata Cushman

Plate 4, figure 1

Quinqueloculina tessellata Cushman, U. S. Geol. Survey Prof. Paper 129-F, p. 142, pl. 33, fig. 8; pl. 34, fig. 1, 1922.

Cushman, U. S. Geol. Survey Prof. Paper 133, p. 54, 1923.

This species is known from the Oligocene Byram marl and Glendon limestone of Mississippi. Specimens are rare in bed 2 but are characteristic, as the figure will show.

\section{Quinqueloculina sp.}

Plate 4, figure 2

A few specimens similar to the one figured have evidences of longitudinal costae, but not enough are available to make it possible to give a definite specific determination or to be sure that these are really adult specimens.

A few poorly preserved specimens may be smooth forms, but they have not been included nor figured, though they indicate that other species are present.

\section{Genus MASSILINA Schlumberger, 1893}

Massilina decorata Cushman

Plate 4, figure 3

Massilina decorata Cushman, U. S. Geol. Survey Prof. Paper 129, p. 143, pl. 34, fig. 7, 1922; Prof. Paper 133, p. 55, 1923.

Howe and Wallace, Louisiana Dept. Cons. Geol. Bull. 2, p. 20, pl. 2, fig. 6, 1932.

This species is very rare in this material, occurring only in bed 5. The species is known from the lower formations of the Oligocene of Alabama and Mississippi and also from the uppermost Eocene of Mississippi.

\section{Genus SPIROLOCULINA D'Orbigny, 1826}

Spiroloculina byramensis Cushman

Spiroloculina byramensis Cushman, U. S. Geol: Survey Prof. Paper 129-E, p. 101, pl. 25, figs. 4a, b, 1922.

A single broken specimen from bed 5 is the only representative of this species in our material but is very typical in its surface characters, with an ornamentation consisting of fine hexagonal depressed areas with raised edges. The species is apparently recorded only from the Byram marl of Mississippi.

\section{Genus PYRGO Defrance, 1824 \\ Pyrgo oligocenica Cushman \\ Plate 4, figure 4}

Pyrgo oligocenica Cushman, Cushman Lab. Foram. Research Contr., vol. 11, p. 26, pl. 4, figs. 5a, b, 1935.

A few specimens of this species were found in bed 5, one of which is figured. The only other record seems to be from the type locality in the Byram marl near Waltersville, Miss. Our specimens are slightly worn and do not show the costae as heavily develop?d as in the type specimen, with which they have been compared, but they are evidently identical with it.

\section{Family OPHTHALMIDIIDAE}

Genus VERTEBRALINA D'Orbigny, 1826

Vertebralina advena Cushman

Plate 4, figure 5

Vertebralina advena Cushman, U. S. Geol. Survey Prof. Paper 129-E, p. 102, pl. 25, figs. 5, 6, 1922; Prof. Paper 133, p. $51,1923$.

Howe, Jour. Paleontology, vol. 2, p. 175, 1928.

Cushman and Hanzawa, Cushman Lab. Foram. Research Contr., vol. 13, p. 44, 1937.

This species is represented in our material by the single specimen figured from bed 5 . Other records are from the Oligocene of the Coastal Plain of Mississippi, all from the Byram marl, except that of Howe from the Red Bluff Clay. 


\section{Family LAGENIDAE}

\section{Genus MaRgINULINA D'Orbigny, 1826}

\section{Marginulina sp.}

Plate 4, figures 6, 7

Three specimens only of a species, which is here figured, were found, but these are not enough to make it possible to apply a definite name. More should be available before it is described in full. They are from bed 5 of our section.

\section{Genus DENTALINA D'Orbigny, 1826}

\section{Dentalina pseudoinvolvens Cushman and McGlamery}

Plate 4, figures 8, 9

Dentalina pseudoinvolvens Cushman and McGlamery, Cushman Lab. Foram. Research Contr., vol. 15, p. 45, pl. 9, figs. 1, 2, 1939 .

Test elongate, slender, slightly arcuate, very gently tapering, with the greatest diameter at the last-formed. chamber, initial end with a short spine; chambers few, about six in the adult, inflated, somewhat pyriform., proloculum fusiform, later chambers increasing very gradually in size as added, more inflated on one side; sutures distinct, depressed, strongly limbate; wall ornamented with distinct, low, longitudinal costae, sometimes tending to become slightly spiral; aperture radiate, at the end of a slightly prolonged, tapering neck. Length, as much as 1.25 millimeters; diameter, 0.15 to 0.18 millimeter.

The types are from bed 5 , but the species also occurs in bed 3 .

This species differs from the Cretaceous species $D$. involvens Cushman in the more separated and inflated chambers, deeper and more limbate sutures, and less prominent costae. It is very similar to a form figured from the Miocene of Florida as Dentalina sp. (Florida Geol. Survey Bull. 9, pl. 9, figs. 3, 4, 1932).

\section{Dentalina cf. D. communis D'Orbigny}

Plate 4, figure 10

A very few specimens from bed 5 , one of which is figured, have a smooth surface. The chambers are somewhat irregular but in general increase rather uniformly in size as added. The aperture is at the outer angle of the last-formed chamber and is radiate.

\section{Dentalina sp.}

Plate 4, figures 11, 12

A few specimens of a peculiar form from bed 5 may belong to Dentalina, although the apertural characters are missing, as all the specimens are broken at the end. The wall is smooth and the chambers are irregular in size.

\section{Genus NODOSARIA Lamarck, 1812}

Nodosaria cf. N. catesbyi D'Orbigny

Plate 4, figures 13-19

In our paper on the Choctaw Bluff section, specimens very similar to those figured here were referred to D'Orbigny's species. ${ }^{6}$ The present material occurs in beds $3,4,5$, and 6 . The specimens show a considerable amount of variation and may be distinct from the Recent West Indian species. Two-chambered and three-chambered specimens are the rule, in which character they are like the Recent species, but our material includes four-chambered and even five-chambered specimens. It is possible that this may be a distinctive species of our Oligocene.

A few specimens seem to have a slightly flattened and irregular early part suggestive of Vaginulina. The later chambers in the two forms are very similar in shape, size, and ornamentation.

\section{Nodosaria vertebralis (Batsch) ? \\ Plate 4, figure 20}

The single specimen figured is from bed 3 of our section. It has more chambers, a thicker wall, and much stronger costae than the preceding species. More specimens are needed to make it possible to determine the species with certainty.

\section{Genus VAGINULINA D'Orbigny, 1826}

\section{Vaginulina sp.}

Plate 4, figure 21

The single specimen here figured is from bed 3 . It is a much flattened form with a strong keel on the dorsal border and with the ventral border truncate, suggesting some of the species referred to Planularia.

Genus LAGENA Walker and Jacob, 1798

Lagena cf. L. lineata Williamson

Plate 4, figure 22

A very few specimens from beds 5 and 6 are rounded, usually with a slight spine at the base and with the surface covered by slightly irregular longitudinal costae. As is generally true of L. lineata, the shape is somewhat irregular, especially at the basal end, which may be asymmetrical.

\section{Lagena striata (D'Orbigny) var. substriata Williamson}

Plate 4, figure 23

A very few specimens with fine costae seem to belong under this variety. They are from beds 1 and 5 . T'ie body of the test is slightly pyriform, and there is a very definite, somewhat elongate neck, slightly tapering to the apertural end.

${ }^{6}$ Cushman, J. A., and McGlamery, Winnie, Oligocene Foraminfera from Choctaw Bluff, Ala.: U. S. Geol. Survey Prof. Paper 189-D, p. 105, pl. 24, fig. 10. 1938. 
Lagena ef. L. striato-punctata Parker and Jones

Plate 4, figure 24

The single specimen figured is from bed 3 and is the only one of the kind so far noted in our material. It resembles $L$. striato-punctata in the peculiar ornamentation of the surface, which consists of longitudinal costae characterized by punctae or tubular structures at regular intervals that give an unique appearance to the costae. In our specimen the short cylindrical neck has spiral costae.

\section{Lagena sulcata (Walker and Jacob)}

Plate 4, figure 25

A very few specimens from bed 5 are similar to that figured here, in which the test is broadly pyriform, broadest below the middle, thence gradually tapering to the acute apertural end. The surface has a comparatively few well-developed acute costae running from base to apex. At the apertural end in our specimens there is a slight enlargement just below the aperture.

\section{Family POLYMORPHINIDAE}

\section{Genus GUTTULINA D'Orbigny, 1839}

Guttulina cf. G. lehneri Cushman and Ozawa

Plate 4, figures 26, 27

Rare specimens may be questionably referred to $G$. lehneri, which has already been recorded from the Oligocene of Choctaw Bluff. ${ }^{7}$ They occur in beds 1, 3, 5 , and 6 and show considerable variation.

\section{Guttulina cf. G. problema D'Orbigny}

Plate 4, figures 28-31

This species has also been recorded from the Oligocene of Choctaw Bluff. Some of the specimens seem to tend toward $G$. lehneri, but the two can usually be easily distinguished. They occur with $G$. lehneri in beds 1 , 3 , and 5 .

\section{Genus GLOBULIN A D'Orbigny, 1826 \\ Globulina gibba D'Orbigny \\ Plate 4, figure 32}

This widely distributed and variable species occurs in considerable numbers in all six beds of the section. It was found also at Choctaw Bluff.

\section{Globulina inaequalis Reuss \\ Plate 4, figure 33}

Globulina inaequalis Reuss, K. Akad. Wiss. Wien Denkschr., vol. 1, p. 377 , pl. 48 , fig. 9,1850 .

Cushman and Ozawa, U. S. Nat. Mus. Proc., vol. 77, art 6, p. 73 , pl. 18, figs. 2-4, 1930.

Cushman, U. S. Geol. Survey Prof. Paper 181, p. 26, pl. 9, fig. 22, 1935 .

Bermudez, Soc. cubana historia nat. Mem., vol. 12, p. 11, 1938.

7 Cushman, J. A., and McGlamery, Winnie, op. cit. (Prof. Paper 189-D), p. 105, pl. 24, fig. 14, 1938 .
The typical form of this species apparently ranges from the upper Eocene to the Miocene of the Gulf Coastal Plain. It occurs in bed 6 .

Globulina inaequalis Reuss var. caribaea D'Orb’ơny

\section{Plate 4, figures 34-36}

Globulina caribaea D'Orbigny, in De la Sagra, Histo*ia física, política y natural de la isla de Cuba, Foramirifères, p. 135 , pl. 2, figs. $7,8,1839$.

Globulina inaequalis Reuss var. caribaea Cushman and Ozawa, U. S. Nat. Mus. Proc. vol. 77, art. 6, p. 75, pl. 18, figs. 5, $6,1930$.

Cole, Florida Geol. Survey Bull. 6, p. 30, pl. 7, fig. 12, 1931.

Cole and Ponton, Florida Geol. Survey Bull. 9, p. 66, pl. 10, fig. 2, 1932.

Specimens from beds 1,3 , and 4 are very similar indeed to Recent specimens of this variety. It has previously been recorded as a fossil from the Pleistocene, Pliocene, and Miocene of the Gulf Coastal Plain, although specimens from the earlier Tertiary of Europe have been referred to it. Living specimens are often found attached to other objects, and one of our specimens is attached in a similar way to a shell fragment.

Globulina alabamensis Cushman and McGlamery

Plate 5, figures 1-4

Polymorphina spinosa Cushman (not D'Orbigny), U. S. Geol. Survey Prof. Paper 129-F, pl. 31, fig. 5, 1922.

Globulina alabamensis Cushman and McGlamery, Cushman Lab. Foram. Research Contr., vol. 15, p. 46, pl. 9, fios. 3a, b, 1939.

Test slightly longer than broad, both ends broadly rounded, periphery broadly rounded, thickness slightly less than the breadth; chambers few, only slightly inflated, increasing rapidly in size as added, lastformed chamber making up at least half the surface in the adult; sutures distinct, sigmoid in the adult, little if at all depressed, very slightly limbate; wall or:namented with numerous short spines, rather evenly s attered over the whole surface; aperture terminal, radiate. Length, 0.60 to 1.25 millimeters; breadth, 0.40 to 1.00 millimeter; thickness, 0.35 to 0.85 millimeter.

The holotype is from bed 3 , but the specie" occurs also in bed 5 .

This species differs from Globulina gibba D'Orbigny var. tuberculata D'Orbigny in the much more distinctive spines and more elongate test, which is also slightly compressed.

\section{Genus POLYMORPHINA D'Orbigny, 1826 \\ Polymorphina frondea (Cushman) \\ Plate 5, figures 5-7}

Bolivina frondea Cushman, U. S. Geol. Survey Prof. Paper 129, p. 126, pl. 29, fig. 3, 1922; Prof. Paper 133, p. 20, 1923.

Polymorphina frondea Cushman, Cushman Lab. Foram. Research Contr., vol. 5, p. 41, 1929.

Cushman and Ozawa, U. S. Nat. Mus. Proc., vol. 77, art. 6 , p. 118, pl. 30, figs. 11a, b, 1930.

Bermudez, Soc. cubana historia nat. Mem., vol. 12, p. 20 , 1938. 
This species occurs in some numbers in beds 3 and 5 . The transverse outline is squarely truncate and often slightly keeled. In some specimens very fine longitudinal costae are weakly developed. No specimens were found that could be referred to the closely allied $P$. advena Cushman, which was found at Choctaw Bluff.

\section{Family NONIONIDAE}

Genus NONION Montfort, 1808

Nonion advenum (Cushman)

Plate 5, figure 8

Nonionina advena Cushman, U. S. Geol. Survey Prof. Paper 129, p. 139, pl. 32, fig. 8, 1922; Prof. Paper 133, p. 50, 1923.

Cushman and Applin, Am. Assoc. Petroleun Geologists Bull., vol. 10, p. 181, pl. 10, figs. 16, 17, 1926.

Nonion advena Howe, Jour. Paleontology, vol. 2, p. 175 (list), 1928.

Cole and Gillespie, Bull. Am. Paleontology, vol. 15, no. 57b, p. 132, pl. 2, fig. 15, 1930 .

Cushman, U. S. Geol. Survey Prof. Paper 181, p. 30, pl. 11, figs. 1-4, 1935; Prof. Paper 191, p. 9, pl. 20, figs. 3, 4, 1939.

Cushman and McGlamery, U. S. Geol. Survey Prof. Paper 189-D, p. 106, pl. 24, figs. 22, 23, 1938.

Typical specimens occur in beds 2, 3, and 6 of this section. It is a widely distributed species in the Oligocene of the Gulf Coastal Plain and occurs at many localities in the upper Eocene of the same area.

\section{Nonion decoratum Cushman and McGlamery}

Plate 5, figure 9

Nonion advenum Cushman and McGlamery (part) (not Cushman), U. S. Geol. Survey Prof. Paper 189-D, p. 106, pl. 24 , fig. 23 (not 24), 1938.

Nonion decoratum Cushman and McGlamery, Cushman Lab. Foram. Research Contr. vol. 15, p. 46, pl. 9, figs. 4 a, b, 1939.

Test planispiral, involute, periphery rounded, lobulate, umbilical area somewhat depressed but with a central boss; chambers very distinet, 8 to 10 in the adult whorl, slightly inflated, increasing rather evenly in size as added; sutures very distinct, deeply excavated, limbate, very slightly curved in the earlier stages, nearly straight and radial in the last-formed portion; wall mostly smooth, finely perforate, the inner portion of the sutures toward the umbilical region, and the central boss ornamented with fine granular projections; aperture, low, elongate, at the base of the last-formed chamber. Length, 0.40 to 0.45 millimeter; breadth, 0.30 to 0.40 millimeter; thickness, 0.20 millimeter.

The holotype is from bed 5 of the section.

This species differs from $N$. advenum Cushman in the more lobulate and more rounded periphery, less deeply excavated sutures, and fewer chambers.

The holotype has two supplementary chambers near the periphery between the last two chambers of the main coil, but this is entirely an accidental feature.
Genus NONIONELLA Cushman, 1926

\section{Nonionella oligocenica Cushman and McGlamery}

Plate 5, figures 10-12

Nonionella danvillensis Cushman and McGlamery (not Howe and Wallace), U. S. Geol. Survey Prof. Paper 189-D, p. 106, pl. 25, fig. 1, 1938.

Nonionella oligocenica Cushman and McGlamery, Cushman Jab. Foram. Research Contr., vol. 15, p. 47, pl. 9, figs. 5a-c, 1939.

Test slightly longer than broad, slightly evolute, periphery broadly rounded, slightly lobulate in the last portion, ventral side slightly umbilicate, dorsal side slightly umbonate; chambers distinct, about ten in the adult whorl, somewhat inflated, more so in the lastformed portion of the adult whorl, increasing gradually and rather evenly in size as added; sutures distinct, earlier ones strongly limbate, curved, not depressed, later ones very slightly curved, depressed; wall smooth and polished, very finely perforate; aperture a low opening at the base of the last-formed chamber, just ventral to the periphery, sometimes with a slight, orerhanging lip. Length, 0.40-0.50 millimeter; breadth, 0.35-0.40 millimeter; thickness, 0.20 millimeter.

This species is common in our section and occurs in beds $1,4,5$, and 6 . The holotype is from bed 1 .

This species differs from Nonionella danvillensis Howe and Wallace in the less prominent umbo on the dorsal side, lack of the elongate projection on the ventral side, and thinner test.

\section{Genus ELPHIDIUM Montfort, 1808}

Elphidium sp.

A very few poorly preserved specimens evidently belong to this genus but do not warrant specific determination.

\section{Family HETEROHELICIDAE \\ Genus NODOGENERINA Cushman, 1927 \\ Nodogenerina? sp. \\ Plate 5, figure 13}

A single specimen from bed 4 is difficult to place. It is uniserial, distinctly and coarsely perforate, with a terminal aperture. There is no true phialine lip, although there is a very slight thickening about the elongated aperture. The early chambers are rounded in section, but later ones become progressively more compressed.

\section{Family BULIMINIDAE}

Genus BULIMINELIA Cushman, 1911

Buliminella cf. B. elegantissima (D'Orbigny) var.

Plate 5, figure 14

Numerous specimens of a form like that figured show the coils extending down and covering the initial end. Such specimens occur in beds $1,3,5$, and 6 . They are 
evidently related to the more definitely spiral form that is more like the Recent species and that occurs at Choctaw Bluff. This variety may be found to be characteristic of this part of the Oligocene.

\section{Genus ROBERTINA D'Orbigny, 1846}

\section{Robertina angusta (Cushman)}

Plate 5, figure 15

Buliminella subteres (H. B. Brady) var. angusta Cushman, U. S. Geol. Survey Prof. Paper 129-F, p. 127, pl. 29, figs. 8, 9, 1922; Prof. Paper 133, p. 24, 1923.

Howe, Jour. Paleontology, vol. 2, p. 174, 1928.

Cushman, Cushman Lab. Foram. Research Contr., vol. 5, p. 42, pl. 7, fig. 5, 1929.

Robertina angusta Cushman and Parker, Cushman Lab. Foram. Research Contr., vol. 12, p. 96, pl. 16, figs. 11a, b, 1936

This species is characteristic of the Oligocene of Mississippi. It is rare in our material, occurring only in bed 5 .

\section{Genus ENTOSOLENIA Ehrenberg, 1848}

Entosolenia crumenata Cushman

Plate 5, figures 16-18

Entosolenia crumenata Cushman, Cushman Lab. Forain. Research Contr., vol. 11, p. 31, pl. 4, figs. 9a, b, 1935.

Cushman and McGlamery, U. S. Geol. Survey Prof. Paper 189-D, p. 109, pl. 26, fig. 11, 1938.

This is evidently a characteristic species of the Oligocene. The type locality is Waltersville (Vicksburg), Miss., and it is a fairly common species at Choctaw Bluff. It occurs in some numbers in beds 3 and 5 .

\section{Entosolenia laevigata (Reuss)}

Plate 5, figures 19-21

This species has already been recorded from Choctaw Bluff as "Entosolenia? sp." 8 Specimens occur in our material in beds 1,3 , and 5 . There is some variation in the series, but the characters as shown in our figure are closely held.

\section{Genus VIRGULINA D'Orbigny, 1826 \\ Virgulina vicksburgensis Cushman \\ Plate 5, figure 22}

Virgulina sp.? Cushman, U. S. Geol. Survey Prof. Paper 129, p. 92 , pl. 16, figs. $2,3,1922$.

Virgulina vicksburgensis Cushman, Cushman Lab. Foram. Research Special Pub. 6, p. 48, pl. 7, figs. 6a, b, 1936; Special Pub. 9, p. 12, pl. 2, figs. 7, 8, 1937.

Cushman and McGlamery, U. S. Geol. Survey Prof. Paper 189-D, p. 107, pl. 25, fig. 9.

This common species of the Vicksburg occurs in our material from beds $1,3,4$, and 5 . It is known from all the marine formations of the Vicksburg and is recorded from Mississippi and Alabama. It also was found in our Choctaw Bluff material.

\footnotetext{
${ }^{8}$ Cushman, J. A., and McGlamery, Winnie, op. cit. (Prof. Paper 189-D), p. 109, pl. 26 , fig. 12,1938
}

\section{Virgulina alabamensis Cushman and McGlamery}

Plate 5, figure 23

Tirgulina alabamensis Cushman and McGlamery, Cushman Lab. Foram. Research Contr., vol. 15, p. 48, p'. 9, figs. $7 \mathrm{a}, \mathrm{b}, 1939$.

Test elongate, somewhat compressed, about three times as long as broad, sides for the most part nearly parallel or decreasing in breadth toward the apertural end, which is somewhat truncate, initial end triserial, bluntly pointed, periphery rounded; chambers numerous, very distinct, about three pairs of biserial ones in the adult, slightly inflated; sutures distinct, curved, slightly depressed; wall thin and nearly transparent, very finely perforate, smooth and polished; sperture rather large, comma-shaped, oblique, with a slight lip. Length, 0.45 to 0.50 millimeter; breadth, 0.12 to 0.15 millimeter; thickness, 0.10 millimeter.

The holotype is from bed 5 of the section. It occurs also in bed 6 .

This species differs from Virgulina bramlettei Galloway and Morrey in the shorter chambers, less coarsely perforate wall, and larger aperture. The form from Choctaw Bluff, ${ }^{9}$ and also that from the Meson (Oligocene) of Mexico, ${ }^{10}$ referred to $V$. bramlettei are probably V.alabamensis.

\section{Genus BOLIVINA D'Orbigny, 1839}

\section{Bolivina tortuosa H. B. Brady}

Bolivina tortuosa H. B. Brady, Micr. Soc. Quart. Jour., vol. 21, p. 57, 1881; Challenger Rept., Zoology, vol. 9, F. 420, pl. 52 , figs $31,32(\operatorname{not} 33,34), 1884$.

Cushman, Cushman Lab. Foram. Research Specis1 Pub. 9, p. 133, pl. 17, figs. 11-19.

Cushman and McGlamery, U. S. Geol. Survey Prof. Paper 189-D, p. 107, pl. 25, figs. 13, 21, 1938.

Specimens of this species were found in material from beds 1, 2, and 4. They are very similar to those from Choctaw Bluff and seem definitely to place this species as a characteristic form of the Oligocene of Alabama. The specimens vary considerably, both in general shape and amount of twisting.

\section{Bolivina paula Cushman and Cahill}

Bolivina paula Cushman and Cahill Ms., cited in Cushman and Ponton, Florida Geol. Survey Bull. 9, p. 84, pl. 12, figs. 6a, b, 1932.

Cushman and Cahill, U. S. Geol. Survey Prof. Faper 175, p. 26, pl. 8, figs. 14a, b, 1933.

Cushman, Cushman Lab. Foram. Research Special Pub. 9, p. 91, pl. 11, fig. 9, 1937.

Cushman and McGlamery, U. S. Geol. Survey Prof. Paper 189-D, p. 107, pl. 25, figs. 14, 18, 19, 1938.

A number of specimens that are narrow, with nearly straight and parallel sides, very low early chambers and smooth wall seem to belong to this species. already recorded from Choctaw Bluff. They may possibly be

${ }^{9}$ Cushman, J. A., and McGlamery, Winnie, op. cit., p 107, pl. 25, fig. 10.

10 Cushman, J. A., Cushman Lab. Foram. Research Special Pub. 9, pl. 3, fig. 8, 1937. 
a variant of B. mississippiensis Cushman. They occur in all six beds.

\section{Bolivina mornhinvegi Cushman}

Bolivina mornhinvegi Cushman, Cushman Lab. Foram. Research Contr., vol. 11, p. 32, pl. 5, figs. 1a, b, 1935; Special Pub. 9, p. 70 , pl. 8, fig. $21,1937$.

Cushman and MeGlamery, U. S. Geol. Survey Prof. Paper 189-D, p. 108, pl. 25, fig. 17, 1938.

The type locality for this species is near Waltersville (Vicksburg), Miss. It has been recorded from Choctaw Bluff and is found in our present material from beds $1,3,5$, and 6 . It is evidently a characteristic species for the Oligocene of this region.

\section{Bolivina quadricosta Cushman and McGlamery}

Bolivina quadricosta Cushman and McGlamery Ms., cited in Cushman, Cushman Lab. Foram. Research Special Pub. 9 , p. 71 , pl. 8 , fig. $23,1937$.

Cushman and MeGlamery, U. S. Geol. Survey Prof. Paper 189-D, p. 108, pl. 25, fig. 20, 1938.

This species was described from the Oligocene of Choctaw Bluff. It has been found in all six of the beds of the present section and seems to be a characteristic species of this part of the Oligocene in Alabama.

\section{Bolivina choctawensis Cushman and McGlamery}

Bolivina choctawensis Cushman and McGlamery Ms., cited in Cushman, Cushman Lab. Foram. Research Special Pub. 9 , p. 72 , rl. 8, fig. 24, 1937.

Cushman and McGlamery, U. S. Geol. Survey Prof. Paper 189-D, p. 108, pl. 26, fig. 4, 1938.

This is another species originally described from the Oligocene of Choctaw Bluff that has proved to be fairly common in the present material, occurring less commonly than B. quadricosta but represented in all the beds.

\section{Bolivina mississippiensis Cushman}

Plate 5, figures 24, 25

Bolivina mississippiensis Cushman, U. S. Geol. Survey Prof. Paper 129-E, p. 92, pl. 15, fig. 5, 1922.

Howe, Jour. Paleontology, vol. 2, p. 174, 1928.

Cushman, Cushman Lab. Foram. Research Special Pub. 9, p. 69 , pl. 8, fig. 16,1937 .

This is a variable species but is confined, so far as known, to the Oligocene. The previous records are all from Mississippi. It is found in our material from beds $1,3,4,5$, and 6 , in some samples in considerable numbers.

\section{Bolivina byramensis Cushman Plate 5, figure 26}

Bolivina caelata Cushman (part), U. S. Geol. Survey Prof. Paper 133, p. 19 (not pl. 2, fig. 2), 1933.

Howe, Jour. Paleontology, vol. 2, p. 17t, 1928.

Cushman, Cushman Lab. Foram. Research Contr., vol. 5, p. 93, pl. 13, fig. 28, 1929.

Cole and Ponton, Florida Geol. Survey Bull. 5, p. 39, pl. 9, fig. 6, 1930.

Nuttall, Jour. Paleontology, vol. 6, p. 20, pl. 5, fig. 3, 1932.

Ellisor, Am. Assoc. Petroleum Geologists Bull, vol. 17, pl. 3, fig. $6,1933$.

286733-41-2
Bolivina caelata Cushman var. byramensis Cushman, U. S. Geol. Survey Prof. Paper 133, p. 19, pl. 1, fig. 9, 1923.

Bolivina byramensis Cushman, Cushman Lab. Foram. Research Special Pub. 9, p. 69, pl. 8, figs. 18-20, 1937.

This is a highly ornamented and characteristic Oligocene species. It has a wide distribution about the Gulf of Mexico and the Caribbean. In our material it is rare, but typical specimens occur in beds 2,3 , and 5 .

\section{Bolivina cf. B. mexicana Cushman}

Plate 5, figure 27

A specimen referred questionably to this Oligocene species was recorded and figured from Choctaw Bluff." A single specimen of the same character was found in our material from bed 1 .

\section{Bolivina cf. B. gracilis Cushman and Applin}

Specimens similar to those from Choctaw Bluff doubtfully referred to this species ${ }^{12}$ occur rarely in our material, especially from bed 4 . Most of the specimens are incomplete and are not entirely like the upper Eocene species. Further specimens are desirable before its exact identity can be satisfactorily determined.

\section{Genus LOXOSTOMA Ehrenberg, 1854}

Loxostoma vicksburgense (Howe)

Plate 5, figure 28

Pleurostomella vicksburgensis Howe, Jour. Paleontology, vol. 4, p. 331, pl. 27, fig. 5, 1930.

Loxostoma vicksburgense Cushman, Cushman Lab. Foram. Research Special Pub. 9, p. 179, pl. 21, fig. 5, 1937.

Cushman and McGlamery, U. S. Geol. Survey Prof. Paper 189-D, p. 108, pl. 26, figs. 6-8, 1938.

This very well characterized species was originally described from the typical Byram marl at Byram, Miss. It occurs in the Chickasawhay marl at Chontaw Bluff in considerable numbers. In the present material it is found in typical form in beds 1,3 , and 5 . The $\varepsilon$,dult character of having the last-formed chamber very thin on one side and caving in is a peculiar feature unlike that of any other species. From the present records it seems to be a characteristic Oligocene species of this region.

\section{Loxostoma sp.}

Plate 6, figures 1,2

An elongate species from bed 5 evidently belongss to Loxostoma. Only the specimens here figured were obtained, and it is impossible to identify them specifically.

\section{Loxostoma dalli (Cushman)}

Bifarina dalli Cushman, Cushman Lab. Foram. Research Contr., vol. 2, p. 31, pl. 4, figs. 5a, b, 1926.

Loxostomum dalli Cushman, U. S. Geol. Survey Prof. Paper 181, p. 38, pl. 15, fig. 3, 1934; Cushman Lab. Foram. Research Special Pub. 9, p. 175, pl. 20, figs. 25-27, $19 £ 7$.

11 Cushman, J. A., and Metlamery, Winnie, op. cit. (Prof. Paper 189-D), p. 108, pl. 26 , fig. 5 .

12 Cushman, J. A., and McGlamery, Winnie, idem, p. 108, pl. 26, figs. 1, 2. 
A single specimen from bed 4 is apparently identical with this species, known hitherto only from the upper Eocene of Alabama. This individual may perhaps be a reworked specimen, but it is recorded here for future reference.

\section{Genus REUSSELLA Galloway, 1933}

Reussella spinulosa (Reuss) var. glabrata (Cushman)

Plate 6, figure 3

Verneuilina spinulosa Reuss var. glabrata Cushman, U. S. Geol. Survey Prof. Paper 129, p. 92, 1922; Prof. Paper 133, p. 21, 1923.

Reussia spinulosa (Reuss) var. glabrata Howe, Jour. Paleontology, vol. 2 , p. $175,1928$.

Cole and Ponton, Florida Geol. Survey Bull. 5 p. 39, 1930.

A single specimen, here figured, from bed 6 seems to belong to this variety. It is known from most of the formations of the Vicksburg group, and its distribution inchudes Mississippi, Ałabama, and Florida.

\section{Genus ANGULOGERINA Cushman, 1927}

Angulogerina byramensis (Cushman)

Plate 6, figures 4-10

Uvigerina byramensis Cushman, U. S. Geol. Survey Prof. Paper 129, pp. 95, 133, pl. 18, fig. 5, 1922; Prof. Paper 133, p. 34, pl. 4 , figs. 10, 11, 1923.

Angulogerina byramensis Ellisor, Am. Assoc. Petroleum Geologists Bull., vol. 17, pl. 3, fig. 16, 1933.

Cushman and McGlamery, U. S. Geol. Survey Prof. Paper 189-D, p. 109, pl. 26, figs. 9, 10, 1938.

This is a very common species, occurring in all six beds. It is a characteristic Oligocene species and is subject to very considerable variation. Our figures show some of the variations in shape and ornamentation.

\section{Angulogerina vicksburgensis Cushman}

Plate 6, figure 11

Angulogerina vicksburgensis Cushman, Cushman Lab. Foram. Research Contr., vol. 11, p. 33, pl. 5, figs. 3, 4, 1935.

Palmer and Bermudez, Soc. cubana historia nat. Mem., vol. 10, p. 293, 1936.

Bermudez, idem, vol. 11, p. 339, 1937.

This rather unique species, described from the Oligocene of Mississippi, occurs in beds 1, 5, and 6 of our section. It has also been recorded from the Oligocene and Eocene of Cuba.

\section{Angulogerina hispidula Cushman and McGlamery}

Plate 6, figure 12

Angulogerina hispidula Cushman and McGlamery, Cushman Lab. Foram. Research Contr., vol. 15, p. 47, pl. 9, figs. $6 a, b, 1939$.

Test elongate, about twice as long as broad, tapering, greatest width formed by the last whorl, early part triangular in section, angles in later part broadly rounded; chambers distinct, later ones strongly inflated, increasing rapidly in size as added; sutures distinct, later ones strongly depressed; wall finely hispid, especially in the earlier part; aperture terminal, elnngate, with a distinct collarlike lip. Length, 0.35 millimeter; diameter, 0.20 millimeter.

The holotype is from bed 1. A single specimen from bed 6 seems also to belong to this species.

\section{Family ELIIPSOIDINIDAE \\ Genus ELLIPSONODOSARIA A. Silvestri, 1900 \\ Ellipsonodosaria? sp.}

Plate 6, figures 13, 14

A very few elongate, chambered specimens similar to that figured were found in beds 5 and 6 . Some of these are more elongate and more regular than others, but no complete ones have been found that would allow specific determination.

\section{Family ROTALIIDAE \\ Genus DISCORBIS Lamarck, 1804}

Discorbis byramensis Cushman

Plate 6, figure 15

Discorbis byramensis Cushman, U. S. Geol. Survey Prof. Paper 129, p. 96, pl. 19, figs. 6-8, 1922; Prof. Paper 1ミ̂, p. 37, 1923.

This is a very well characterized species known only from the Oligocene Byram marl of Mississippi. It is of interest therefore to record a typical specimen from bed 3 of our section. This, with other species, should serve to correlate very closely these Alabama beds with the Mississippi section.

\section{Discorbis subaraucana Cushman \\ Plate 6, figures 17, 18}

Discorbis subaraucana Cushman, Carnegie Inst. Weshington Pub. 311, p. 41, pl. 7, figs. 1, 2, 1922; U. S. Geo'. Survey Prof. Paper 181, p. 43, pl. 18, figs. 1a-c, 1935.

Cushman and McGlamery, U. S. Geol. Survey Prof. Paper 189, p. 109, pl. 26, fig. 13, 1938.

This is a long-ranging species, recorded from upper Eocene to Recent. It is abundant in our material and is represented in all six beds of the section. There is comparatively little variation in the series.

\section{Discorbis subpatelliformis Cushman and McGlamery}

\section{Plate 6, figure 16}

Discorbis patelliformis Cushman (not H. B. Brady), U. S. Geol. Survey Prof. Paper 133, p. 38, pl. 6, figs. 2-4, 1923.

Discorbis subpatelliformis Cushman and McGlamery, Cushman Lab. Foram. Research Contr., vol. 15, p. 48, fl. 9, figs. 8 a-c, 1939.

Test plano-convex, dorsal side moderately but evenly convex, ventral side flattened or slightly concave, periphery slightly rounded without a keel; chambers distinct, five or six in the adult whorl, of uniform shape, very gradually and regularly increasing in size as added, not 
inflated; sutures distinct, not depressed, those of the dorsal side strongly oblique, slightly curved, sigmoid on the ventral side; wall on the dorsal side smooth, finely perforate, on the ventral side with numerous, distinct, fine beads, more strongly developed in the ventral region but not arranged in any definite pattern; aperture a low opening on the ventral border of the last-formed chamber. Diameter, 0.30 to 0.35 millimeter; height, 0.10 millimeter.

The holotype is from bed 6 of the section.

This species differs from Discorbis patelliformis $\mathbf{H}$. B. Brady in the very flattened spire, sharp periphery, less definitely beaded ventral side with the beads mostly confined to the umbilical region and not arranged in radial lines.

\section{Genus LAMARCKINA Berthelin, 1881}

\section{Lamarckina glabrata (Cushman)}

Pulvinulina glabrata Cushman, U. S. Geol. Survey Prof. Paper 129 , pp. 99, 138, pl. 22, figs. 6, 7, 1922; Prof. Paper 133, p. 45 , pl. 6 , figs. $11,12,1923$.

Lamarckina glabrata Cushman, Cushman Lab. Foram. Research Contr., vol. 2, p. 11, pl. 1, figs. 6 a-c, 1926.

Howe, Jour. Paleoutology, vol. 2, p. 175, 1928.

Cushman and McGlamery, U. S. Geol. Survey Prof. Paper 189 , p. 109, pl. 26, fig. 17.

Specimens of this characteristic Oligocene species are very rare in our material. The only occurrence is in bed 2, and specimens are not well-preserved though identifiable.

\section{Genus VALVULINERIA Cushman, 1926}

\section{Valvulineria paucilocula Cushman}

$$
\text { Plate 6, figure } 19
$$

Valvulineria paucilocula Cushman, Cushman Lab. Foram. Research Contr., vol. 11, p. 37, pl. 5, figs. 7 a-c, 1935.

Test rounded, somewhat compressed, periphery broadly rounded, dorsal side slightly convex, ventral side slightly concave in the center; chambers distinct, five in the adult whorl, of rather uniform shape, increasing regularly in size as added, the last-formed chamber making up on the ventral side nearly one-half the surface; sutures distinct, slightly depressed, gently curved; wall thin, coarsely and distinctly perforate except in a clear area above the aperture on the ventral side; aperture an elongate, arched opening on the ventral side, with a flattened, somewhat angular projecting lip above it. Length 0.35 to 0.40 millimeter; breadth, 0.30 millimeter; thickness, 0.20 millimeter.

The types of this species are from the Oligocene Byram marl, 8 feet above ledge at water's edge, under suspension bridge on Pearl River, Byram, Miss. It is fairly common in our material from beds $1,4,5$, and 6 of the section. As it has not previously been recorded since the first reference, the complete description is repeated here. It should be a good species for correlation of the Oligocene.

\section{Valvulineria sculpturata Cushman} Plate 6, figure 21

Valvulineria sculpturata Cushman, Cushman Lab. Fcram. Research Contr., vol. 11, p. 37, pl. 5, figs. 10a-c, 1935.

Test trochoid, somewhat longer than broad, dorsally flattened or somewhat concave, ventrally convex except for a slight depression in the umbilical region, periphery lobulate, rounded in edge view; chambers distinct in the adult whorl, four or five in number, increasing somewhat in length as added, on the ventral side strongly convex, on the dorsal side with the outer half convex, the inner half strongly excavated; sutures distinct, depressed, strongly curved dorsally, les so ventrally; wall very coarsely perforate; aperture or the ventral side, nearly* umbilical, with a rather thick projecting lip above the aperture itself. Length, 0.30 millimeter; breadth, 0.20 millimeter; thickness, 0.15 to 0.18 millineter.

The types are from the Byram marl, 30 feet above a limestone ledge, bottom of hill on road ascending from Waltersville (Vicksburg), Miss., to National Cemetery.

It is interesting to find this distinctive species in our material from Alabama. It is from bed 5 . No other record of it has been made since the original description, which is repeated above.

\section{Genus GYROIDINA D'Orbigny, 1826 \\ Gyroidina sp. \\ Plate 6, figure 20}

A very few specimens of a small species in our material resemble forms of Gyroidina soldanii D'Orbigny but do not have as many chambers as the variety octocamerata Cushman and G. D. Hanna. These specimens occur in beds 4,5 , and 6 and seem to represent young stages.

\section{Genus EPONIDES Montfort, 1808 \\ Eponides byramensis (Cushman) \\ Plate 6, figure 22}

Pulvinulina byramensis Cushman, U. S. Geol. Survey Prof. Paper 129, pp. 99, 138, pl. 22, figs. 4, 5, 1922; Prof. Paper 133, p. 44, 1923.

Eponides byramensis Howe, Jour. Paleontology, vol. 2, p. 174, 1928.

Cole, Bull. Am. Paleontology, vol. 15, p. 4, 1929.

Cole and Ponton, Florida Geol. Survey Bull. 5, p. 41, pl. 8, figs. 5, 6, 1930.

Cole and Gillespie, Bull. Am. Paleontology, vol. 15, p. 12, pl. 2, figs. 1, 2, 1930.

Nuttall, Jour. Paleontology, vol. 16, p. 26, 1932.

Pijpers, Geology and paleontology of Bonaire, p. 70, 1933.

Hedberg, Jour. Paleontology, vol. 11, p. 679, pl. 92, fig. 2a, b, 1937 .

Burmudez, Soc. cubana historia nat. Mem., vol. 12, p. 6, 1938.

This common Oligocene species, known from all the formations of the Vicksburg of Mississippi, is found in our present material from beds $3,4,5$, and 6 . The early stages may be confused with $E$. albamensis Cushman and McGlamery, but the later development of the two species is distinctive. 
Eponides alabamensis Cushman and McGlamery

Plate 7, figure 1

Eponides alabamensis Cushman and McGlamery, U. S. Geol. Survey Prof. Paper 189, p. 110, pl. 27, fig. 2, 1938.

This species was described from the Chickasawhaymarl at Choctaw Bluff, Ala. It occurs in considerable numbers in our material from beds $1,3,4$, and 5 .

\section{Eponides choctawensis Cushman and McGlamery}

Eponides choctawensis Cushman and McGlamery, U. S. Geol. Survey Prof. Paper 189, p. 110, pl. 27, fig. 1, 1938.

A single specimen from bed 3 in our material seems identical with this species, described from the Chickasawhay marl at Choctaw Bluff, Alq̣.

\section{Genus ROTALIA Lamarck, 1804}

\section{Rotalia byramensis Cushman}

Rotalia byramensis Cushman, U. S. Geol. Survey Prof. Paper 129, pp. 99, 128, pl. 23, fig. 1, 1922; Prof. Paper 133, p. 46, 1923.

Cushman and McGlamery, U. S. Geol. Survey Prof. Paper 189 , p. 110, pl. 27, fig. 3, 1938.

This is a characteristic species of the American Oligocene. It is fairly common in our section, occurring in beds 2, 4, and 6 . The species was also found at Choctaw Bluff, Ala.

\section{Rotalia alabamensis Cushman and McGlamery}

Rotalia alabamensis Cushman and MeGlamery, U. S. Geol. Survey Prof. Paper 189, p. 110, pl. 27, fig. 5, 1938.

This species was described from the Oligocene at Choctaw Bluff, Ala. In the present material there are two typical specimens from bed 5 .

\section{Genus SIPHONINA Reuss, 1850 \\ Siphonina advena Cushman}

Plate 7, figures 2, 3

Siphonina advena Cushman, U. S. Geol. Survey Prof. Paper 129, pp. 98, 137, pl. 22, figs. 1, 2, 1922 ; Prof. Paper 133, p. 42, 1923; U. S. Nat. Mus. Proc., vol. 72, p. 7, pl. 1, figs. 7a-c, 1927.

Howe, Jour. Paleontology, vol. 2, p. 175, 1928.

Cole, Bull. Am. Paleontology, vol. 15, p. 4, 1929.

Cole and Gillespie, Bull. Am. Paleontology, vol. 15, p. 12, pl. 4, figs. 5, 6, 1930.

Cole and Ponton, Florida Geol. Survey Bull. 5, p. 43, pl. 11, figs. 7, 8, 1930.

Ellisor, Am. Assoc. Petroleum Geologists Bull., vol. 17, pI. 3, fig. 22, 1933.

Bermudez, Soc. cubana historia nat. Mem., vol. 12, p. 22, 1938.

This species is recorded from all nurine formations of the Oligocene Vicksburg group of the Gulf Coastal Plain, occurring in Mississippi, Alabama, Florida, and Texas. It is recorded from the Oligocene Meson formation of Mexico and has lately been recorded by Bermudez from the upper Eocene of Cuba. It is found in considerable numbers in our material and is represented in all six beds. It seems strange that it should not have appeared in our material from Choctaw Bluff, but was apparently absent there.

\section{Genus CANCRIS Montfort, 1808}

Cancris sagra (D'Orbigny) var. pauciloculata Cushran and McGlamery

Pulvinulina sagra Cushman (not D'Orbigny), U. S. Geol. Survey Prof. Paper 133, p. 45, pl. 6, figs. 9, 10, 1933.

Cancris sagra (D'Orbigny) var. pauciloculata Cushman and McGlamery, U. S. Geol. Survey Prof. Paper 189, p. 110 , pl. 27, fig. 6, 1938 .

This variety, described from Choctaw Bluft, is represented by a single specimen from bed 5 . Tre only other record for it is from the Glendon limestone at Vicksburg. Miss.

\section{Family AMPHISTEGINIDAE Genus ASTERIGERINA D'Orbigny, 1839 \\ Asterigerina bracteata Cushman}

Asterigerina bracteata Cushman, Cushman Lab. Foram. Pesearch Contr., vol. 5, p. 48, pl. 8, figs. 6a-c, 1939.

Cushman and McGlamery, U. S. Geol. Survey Prof. Paper 189, p. 111, pl. 28, fig. 3, 1938.

This species is recorded from the Oligocene Byram marl at Byram, Mississippi, and from the Chickasawhay marl at Choctaw Bluff. It is abundant near Millry in beds $1,2,3,5$, and 6 .

\section{Asterigerina choctawensis Cushman and McGlarery} Plate 7, figure 4

Asterigerina choctawensis Cushman and McGlamery, U. S. Geol. Survey Prof. Paper 189, p. 111, pl. 28, fig. 2, 1938.

This species, recently described from the Oligocene of Choctaw Bluff, is represented in our present material by a single specimen from bed 4 .

\section{Asterigerina alabamensis Cushman and McGlamery Plate 7, figure 5}

Asterigerina alabamensis Cushman and McGlamery, U. S. Geol. Survev Prof. Paper 189, p. 111, pl. 28, fig. 5, 193?.

This species is represented by a single specimen from bed 4. It was originally described from the Chickasawhay marl at Choctaw Bluff.

Genus AMPHISTEGINA D'Orbigny, 1826

\section{Amphistegina sp.}

Numerous specimens evidently belonging to this genus were found in all six of the beds in our section. The adult forms are, however, invariably eroded and usually broken, and do not preserve details for specific identification.

\section{Family CASSIDULINIDAE \\ Genus CASSIDULINA D'Orbigny, 1826 \\ Cassidulina ef. C. crassa D'Orbigny \\ Plate 7, figure 6}

Small specimens with a rounded periphery, such as here figured, may be referred somewhat questionably to this species. They are from beds 1,5 , and 6 . Similar specimens were found in the Chickasawhay marl at Choctaw Bluff. 


\section{Cassidulina cf. C. laevigata D'Orbigny}

Plate 7, figure 7

A single specimen with an acute periphery and smooth surface, here figured, is from bed 3 and may be questionably referred to D'Orbigny's species.

\section{Family ANOMALINIDAE}

\section{Genus ANOMALINA D'Orbigny, 1826}

\section{Anomalina bilateralis Cushman}

Anomalina bilateralis Cushman, U. S. Geol. Survey Prof. Paper 129, pp. 97, 137, pl. 21, figs. 1, 2, 1922; Prof. Paper 133, p. $42,1923$.

Howe, Jour. Paleontology, vol. 2, p. 174, 1928.

Cole and Ponton, Florida Geol. Survey Bull. 5, p. 46, pl. 10, figs. 8, 9, 1930 .

Ellisor, Am. Assoc. Petroleum Geologists Bull., vol. 17, pl. 4, fig. 9, 1933.

Cushman, U. S. Geol. Survey Prof. Paper 181, p. 50, pl. 21, figs. 4, 5, 1935.

Bermudez, Soc. cubana historia nat. Mem., vol. 11, p. 339, 1937.

This species is recorded from the Oligocene of the Gulf Coastal Plain and also from the upper Eocene of Mississippi, Alabama, and Georgia. Bermudez has recorded it from the upper Eocene of Cuba. In our material it is found rather rarely in beds 1,3 , and 6 and more commonly in bed 5 .

\section{Genus CIBICIDES Montfort, 1808}

Cibicides americanus (Cushman)

Plate 7, figures $8-10$

Truncatulina americana Cushman, U. S. Geol. Survey Bull. 676, p. 63 , pl. 20, figs. 2,3 ; pl. 21, fig. 1, 1918 .

Cibicides americanus Cole and Gillespie, Bull. Am. Paleontology, vol. 15 , no. 57 b, p. 14 , pl. 4 , fig. $4,1930$.

Cushman, Florida Geol. Survey Bull. 4, p. 61, pl. 12, figs. 5a-c, 1930.

Cole and Pouton, Florida Geol. Survey Bull. 5, p. 48, pl. 7, figs. 5, 6, 1930.

Cushman and Parker, Cushman Lab. Foram. Research Contr., vol. 7, p. 15, pl. 3, figs. 1a-c, 1931.

Cushman and Cahill, U. S. Geol. Survey Prof. Paper 175, p. 34, pl. 13, figs. 2a-c, 1933.

Cushman and Laiming, Jour. Paleontology, vol. 5, p. 119, pl. 14, figs. ba-c, 1931.

Nuttall, Jour. Paleontology, vol. 6, p. 32, pl. 7, figs. 10, 11, 1932.

Hedberg, Jour. Paleontology, vol. 11, p. 682, 1937.

This species is widely distributed in the American Miocene and Oligocene. It is recorded from the Gulf Coastal Plain, from the Miocene of California, and from the Oligocene of Mexico and Venezuela. In our material it is common and is represented in all six beds.

Cibicides cf. C. lobatulus (Walker and Jacob)

Plate 7, figures 11-13

Specimens of this variable species occur in all six beds of our section and show the usual range of variation.

$286733-42-3$
Cibicides mississippiensis (Cushman)

Plate 7, figure 14

Anomalina mississippiensis Cushman, U. S. Geol. Survey Prof. Paper 129, pp. 98, 137, pl. 21, figs. 6-8, 1922; Prof. Paper 133 , p. $42,1923$.

Howe, Jour. Paleontology, vol. 2, p. 174, 1928.

Cole and Ponton, Florida Geol. Survey Bull. 5, p. 46, pl. 9, figs. 2, 3, 1930.

Cibicides mississippiensis Ellisor, Am. Assoc. Petroleum Geologists Bull., vol. 17, pl. 5, figs. 6, 7, 1933.

Cushman, U. S. Geol. Survey Prof. Paper 181, p. 54, pl. 22, figs. 3a-c, 1935.

Specimens of this species are not as common in our material as are those of the two preceding species but they are found in beds 1, 4, and 5. Typical specimens occur in the Oligocene, but those of the upper Eocene are not so typical.

\section{Family PLANORBULINIDAE \\ Genus PLANORBULINA D'Orbigny, 1826}

Planorbulina larvata Parker and Jones

Plate 7, figures 15,16

Planorbulina vulgaris D'Orbigny var. larvata Parker and Jones, Annals and Mag. Nat. Hist., 3d ser., vol. 5, p. 294, 1860.

Planorbulina larvata Parker and Jones, Philos. Trans., vol. 155, p. 379, pl. 19, figs. 3a, b, 1865.

H. B. Brady, Challenger Rept., Zoology, vol. 9, p. 658, pl. 92, figs. 5, 6, 1884.

Heron-Allen and Earland, Zool. Soc. London Trans., vol. 20, p. 706, 1915.

Cushman, U. S. Nat. Mus. Bull. 71, pt. 5, p. 27, pl. 8, fix. 2, fig. 30 (in text), 1915; U. S. Geol. Survey Prof. Prper 133, p. 39, pl. 6, figs. 7, 8, 1923.

Hadley, Bull. Am. Paleontology, vol. 20, p. 30, pl. 5, fir. 9, 1934.

Numerous specimens seem to belong to this typically Indo-Pacific species. They occur in beds $1,3,4,5$, and 6. Two specimens are figured. It has alre ${ }^{-1 y}$ been recorded from the upper formations of the Oligocene of Mississippi and the Marianna limestone of Alabanı. Hadley records it from the Oligocene of Cuba.

\section{Family ORBITOIDIDAE}

Genus LEPIDOCYCLIN A Gümbel, 1868

Specimens of orbitoid Foraminifera were submitted to Dr. T. Wayland Vaughan, who has given us the following notes in regard to them:

Ped 2. Bed 6.

Lepidocyclina sp., species not identifiable.

Lepidocyclina (Eulepidina) cf. L. undosa Cushman var. More discoid than $L$. undosa, not so selliform.

Geological horizon: Oligocene, middle or upper-not lower Oligocene.

I lave ground three specimens from bed 6 to the equatorial plane and have exposed the embryonic and equatorial chambers in each. Two of the specimens ground on one side are not at all saddle-shaped, as are most specimens of Lepidocyclina undosa, but in the same lot there are other specimens that are selliform. Although the flat specimens are not typical $L$. undosa, I should hesitate to apply another name to them.-T. $W . V$. 

P LAT E S $4-7$ 
PLATE 4

Frgure 1. Quinqueloculina tessellata Cushman, $\times 50 \ldots$

2. Quinqueloculina sp., $\times 50 \ldots$

3. Massilina decorata Cushman, $\times 55$

4. Pyrgo oligocenica Cushman, $X 55 \ldots$

5. Vertebralina advena Cushman, $\times 100$

6, 7. Marginulina sp., $\times 50$.

11, 12. Dentalina sp., $\times 30 \ldots \ldots$

13-19. Nodosaria ef. $N$. catesbyi D'Orbigny, $\times 65 \ldots$

20. Nodosaria vertebralis (Batsch)?, $\times 55 \ldots$

21. Vaginulina sp., $\times$ 70_

22. Lagena ef. L. lineata Williamson, X 145

23. Lagena striata (D'Orbigny) var. substriata Williamson, $\times 55 \ldots$

24. Lagena cf. L. striato-punctata Parker and Jones, $\times 115 \ldots \ldots \ldots$

25. Lagena sulcata (Walker and Jacob), $\times 100$

26, 27. Guttulina ef. $G$. lehneri Cushman and Ozawa, $\times 50 \ldots$

28-31. Guttulina cf. G. problema D'Orbigny, $\times 40$.

32. Globulina gibba D'Orbigny, $\times 75 \ldots \ldots \ldots$

33. Globulina inaequalis Reuss, $\times 50 \ldots$

34-36. Globulina inaequalis Reuss var. caribaea D'Orbigny. $34,35, \times 35 ; 36, \times 80$ 78 


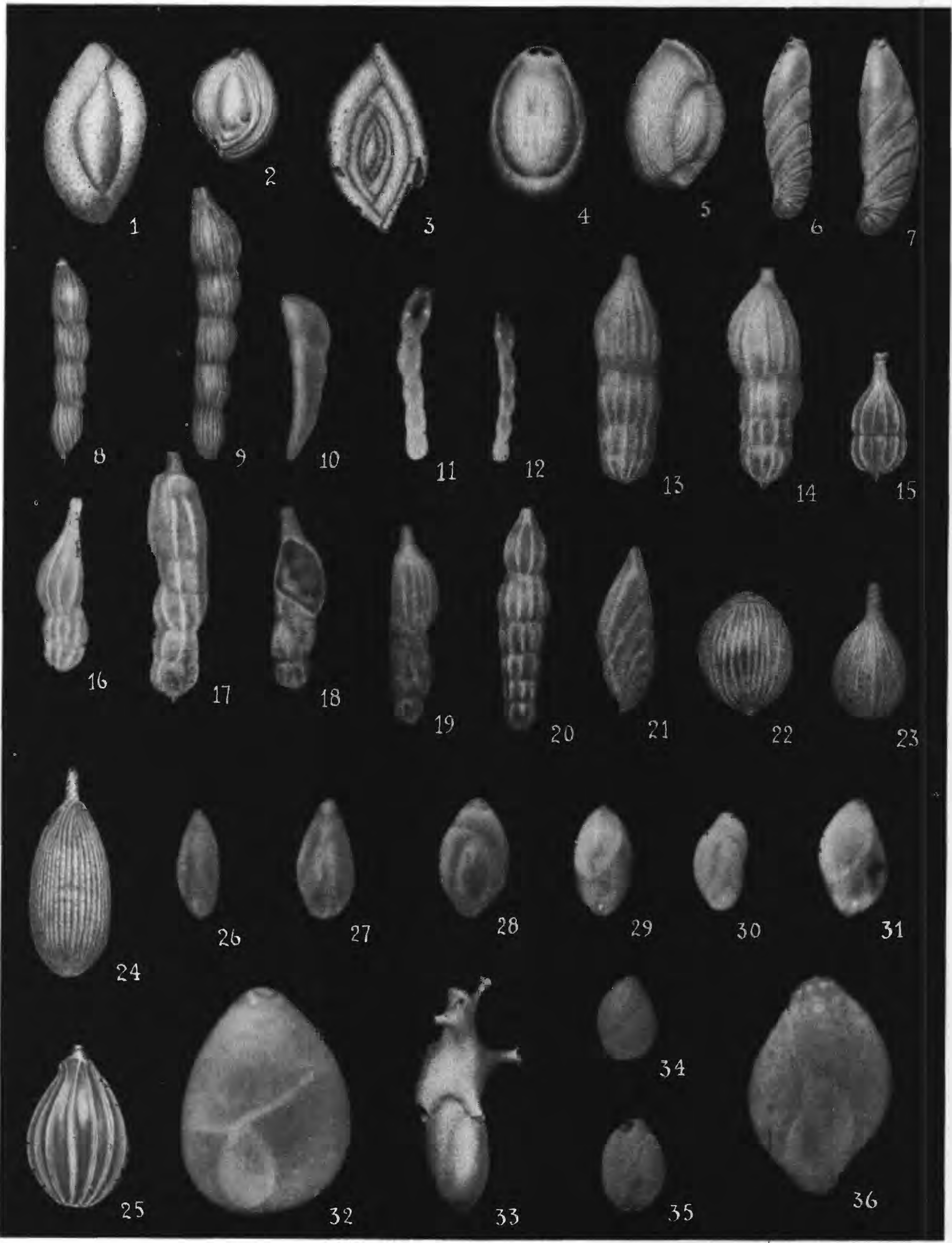

MILIOLIDAE, OPHTHALMIDIIDAE, LAGENIDAE, AND POLYMORPHINIDAE. 


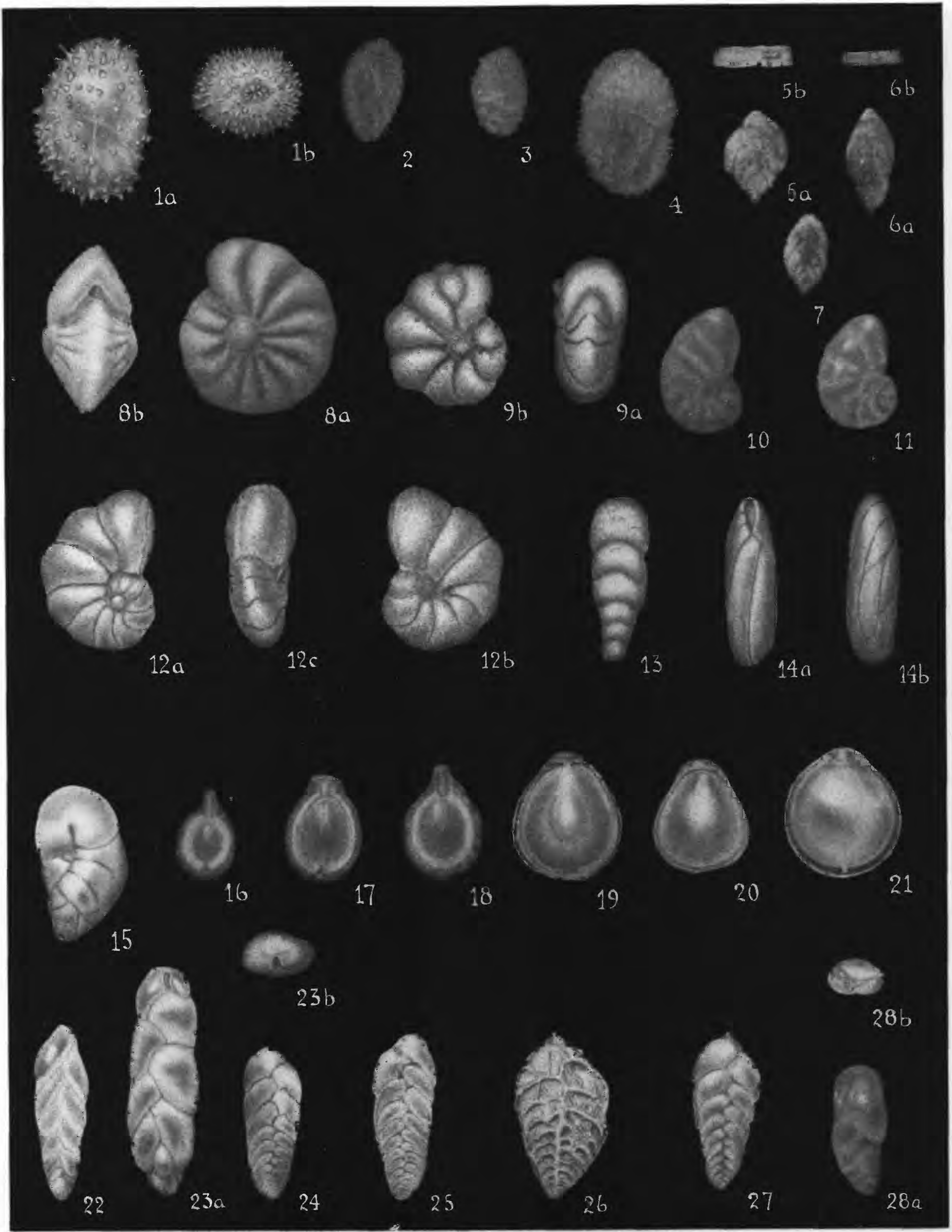




\section{PLATE 5}

Figures 1-4. Globulina alabamensis Cushman and McGlamery. 1, Holotype, a, front view; b, apertural view, $\times 50$. 2-4, Paratypes, $\times 30 \ldots \ldots$.

5-7. Polymorphina frondea (Cushman), $\times 40$. 5a, 6a, Front views; $5 \mathrm{~b}, 6 \mathrm{~b}$, apertural views

8. Nonion advenum (Cushman), $\times 75$. a, Side view; $b$, peripheral view $\ldots$

9. Nonion decoratum Cushman and McGiamery, $\times 75$. a, Side view; b, peripheral view ...............

10-12. Nonionella oligocenica Cushman and McGlamery, $\times 75.10,11$, Paratypes. 12, Holotype, a, b, opposite sides; c, peripheral view

13. Nodogenerina? sp., $\times 160 \ldots$

14. Buliminella cf. $B$. elegantissima (D'Orbigny) var., $\times 160$. a, Front view; b, rear view $\ldots$

15. Robertina angusta (Cushman),$\times 115$.

16-18. Entosolenia crumenata Cushman, $\times 65$

19-21. Entosolenia laevigata (Reuss), $\times 130 \ldots \ldots \ldots \ldots$

22. Virgulina vicksburgensis Cushman, $\times 65 \ldots$

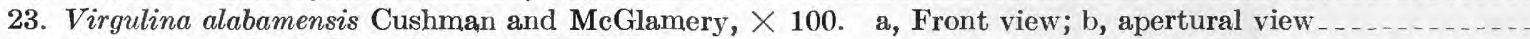

24, 25. Bolivina mississippiensis Cushman, $\times 65$

26. Bolivina byramensis Cushman, $\times 70_{\ldots} \ldots$

27. Bolivina cf. B. mexicana Cushman, $\times 65 \ldots$

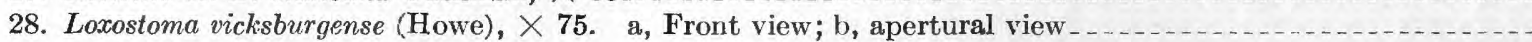




\section{PLATE 6}

Figures 1, 2. Loxostoma sp., $\times 75$

3. Reussella spinulosa (Reuss) var. glabrata (Cushman), × $160 \ldots$

4-10. Angulogerina byramensis (Cushman), $\times 75$

11. Angulogerina vicksburgensis Cushman, $X 115 \ldots$

12. Angulogerina hispidula Cushman and McGlamery, $\times 105$. a, Front view; b, apertural view .......... 72

13, 14. Ellipsonodosaria? sp. $13, \times 25 ; 14, \times 35 \ldots$

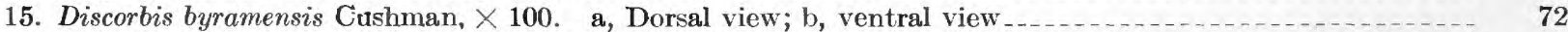

16. Discorbis subpatelliformis Cushman and McGlamery, $\times 105$. a, Dorsal view; b, ventral view; $c$, peripheral view

17, 18. Discorbis subauracana Cushman, $\times 55$. $17 \mathrm{a}, 18 \mathrm{a}$, Dorsal views; $17 \mathrm{~b}, 18 \mathrm{~b}$, ventral views; $17 \mathrm{c}$, $18 \mathrm{c}$, peripheral views.

19. Valvulineria paucilocula Cushman, $\times 100$. $a$, Dorsal view; $b$, ventral view; $c$, peripheral view ..........

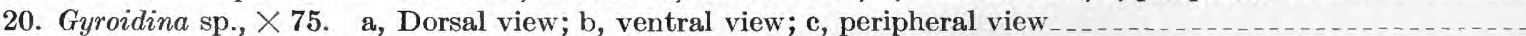

21. Valvulineria sculpturata Cushman, $X 100$. a, Dorsal view; b, ventral view; c, peripheral view ..........

22. Eponides byramensis (Cushman), $\times 50$. a, Dorsal view; $b$, ventral view; $c$, peripheral view $\ldots$ 80 


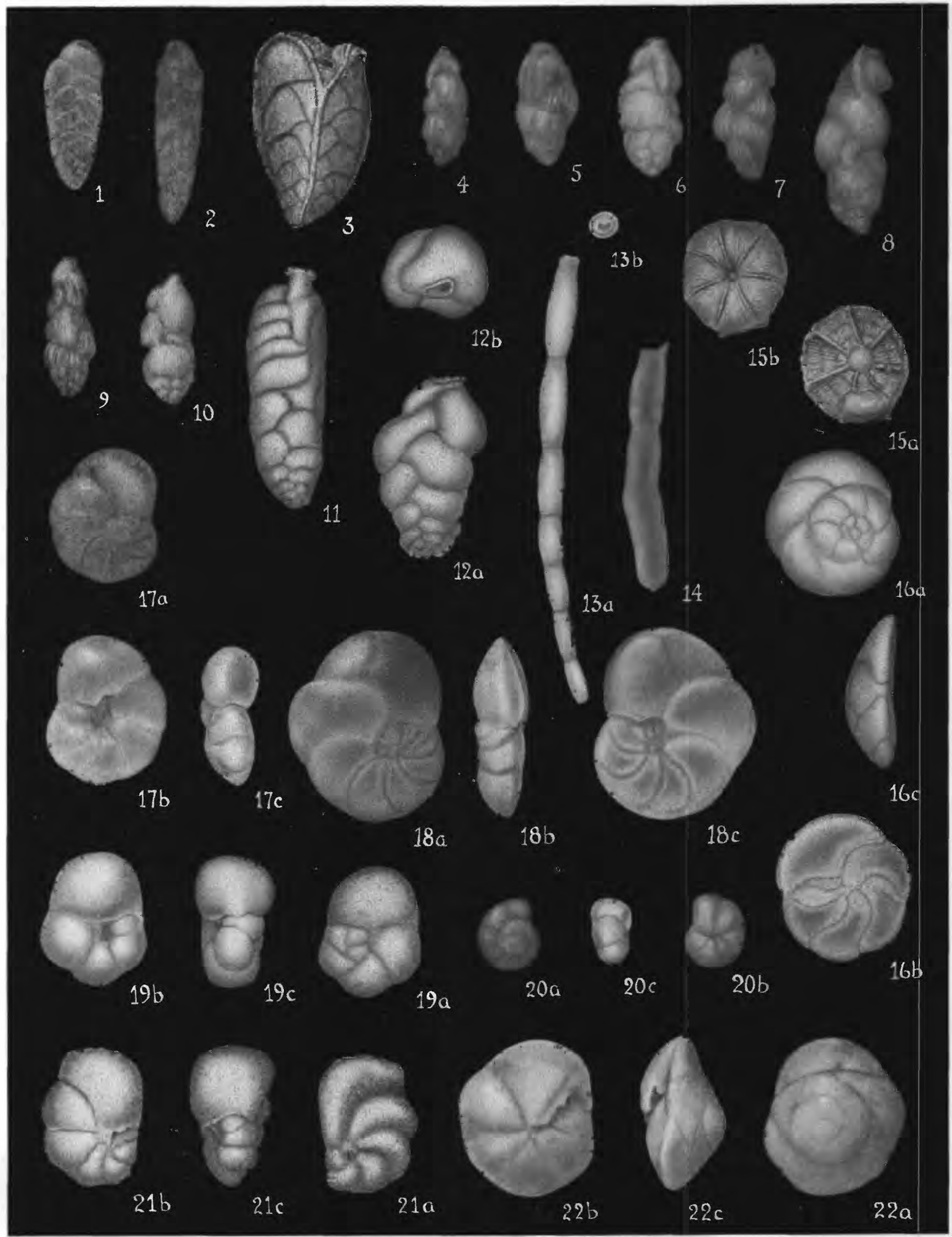

BULIMINIDAE, ELLIPS,OIDINIDAE, AND RO'TALIIDAE. 

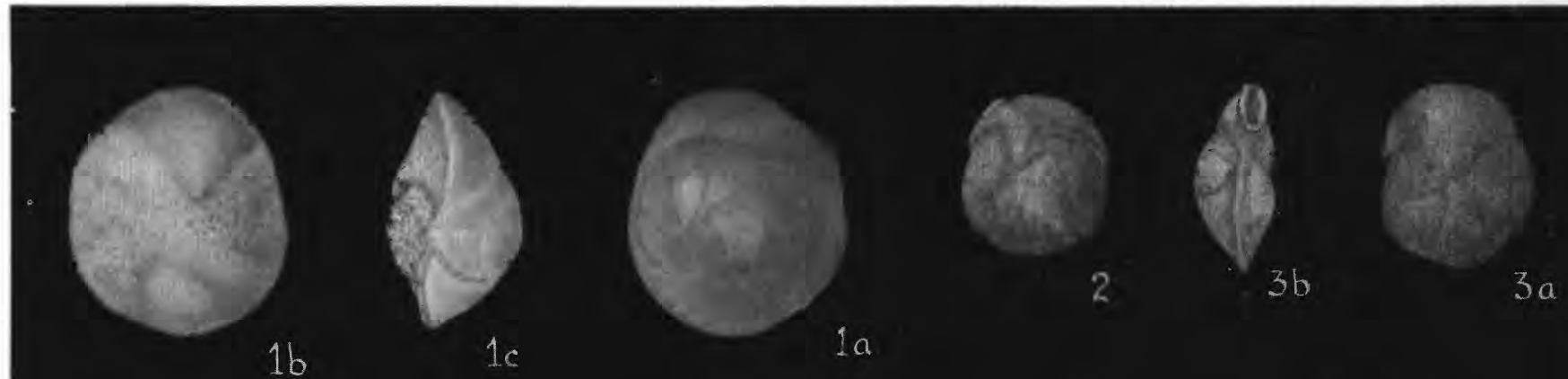

4a
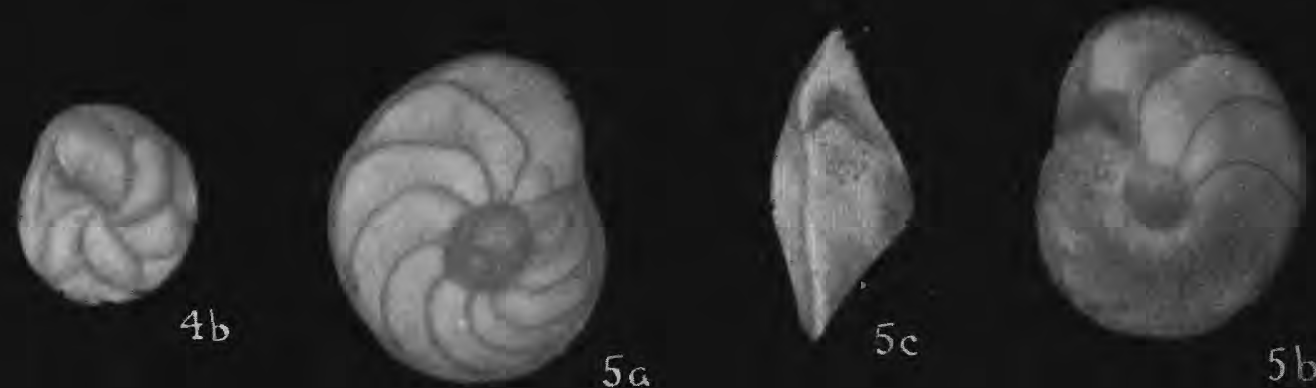

$5 a$
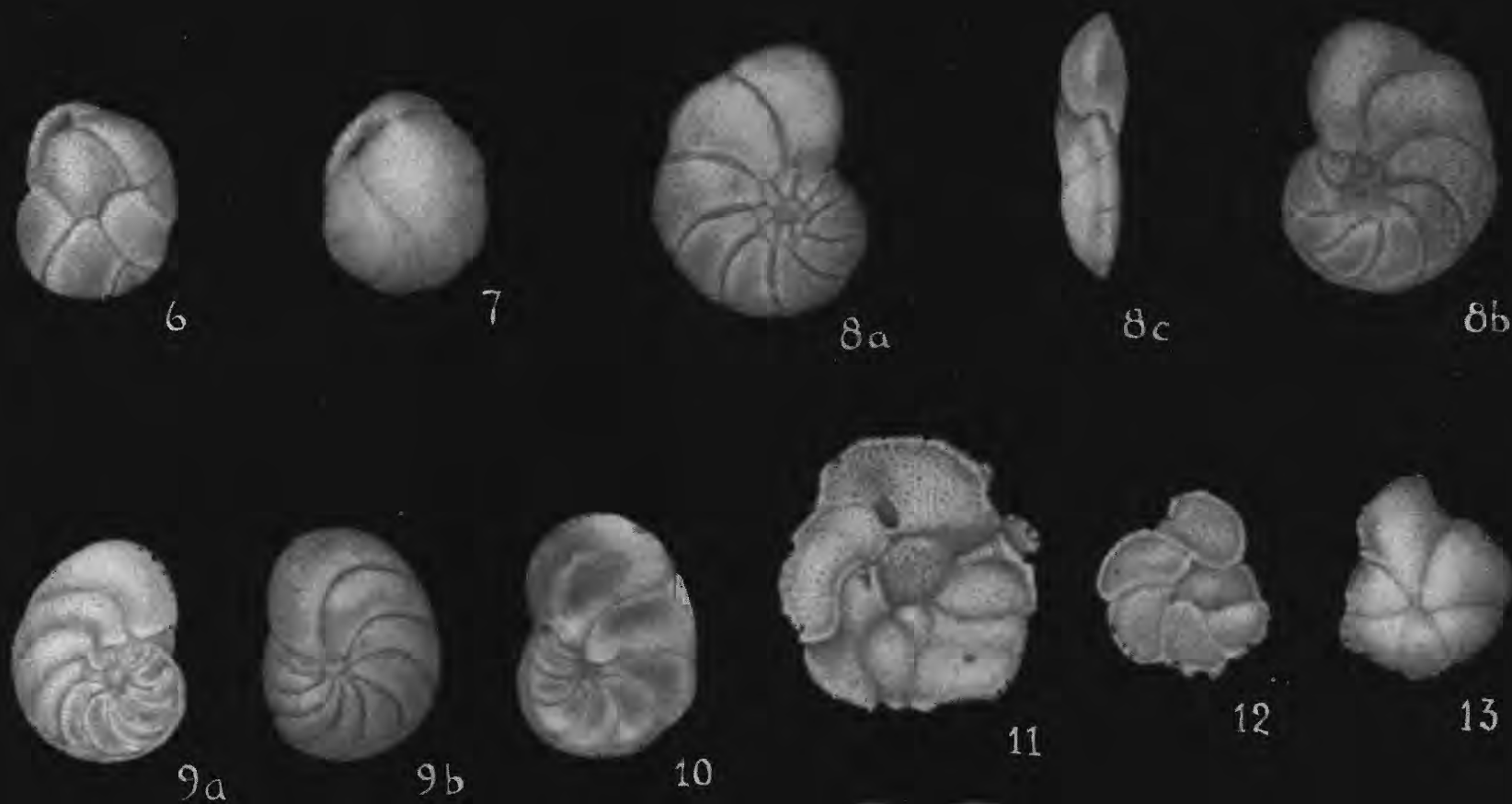

10
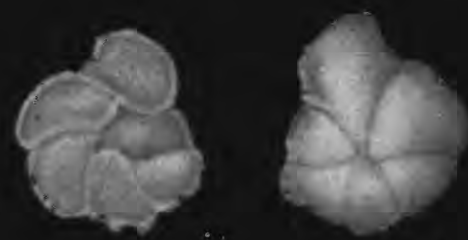

11

12

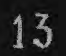

$9 b$
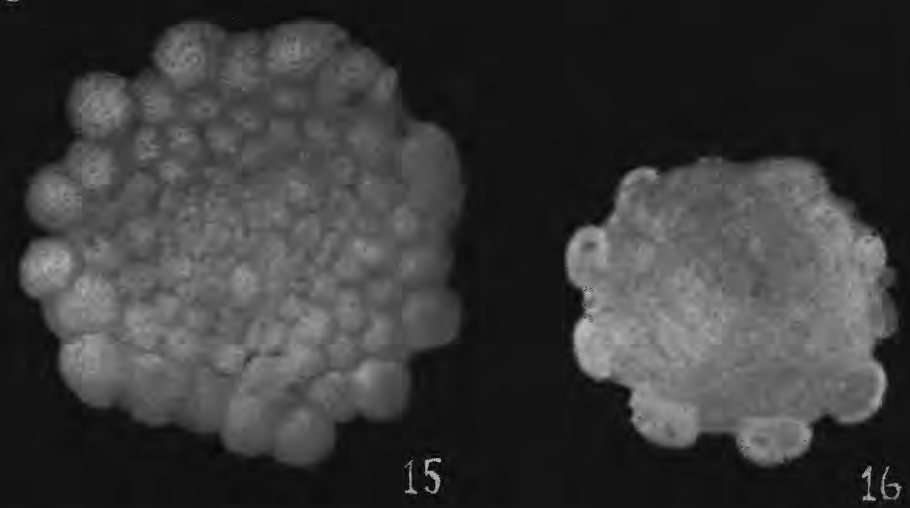

ROTALIIDAE, AMPHISTEGINIDAE, CASSIDULINIDAE, ANOMALINIDAE, AND PLANORBULINIDAE. 


\section{PLATE 7}

FigUre 1. Eponides alabamensis Cushman and McGlamery, $\times 50$. a, Dorsal view; b, ventral view; c, peripheral view

2, 3. Siphonina advena Cushman, $\times 50$. 2, Dorsal view. $3 \mathrm{a}$, ventral view; $3 \mathrm{~b}$, peripheral view

4. Asterigerina choctawensis Cushman and McGlamery, $\times 50$. 4a, Dorsal view; $4 \mathrm{~b}$, ventral view

5. Asterigerina alabamensis Cushman and McGlamery; $\times 75$. a, Dorsal view; b, ventral view; c, peripheral view

6. Cassidulina of. C. crassa D'Orbigny, $\times 130$

7. Cassidulina ef. C. laevigata D'Orbigny, $\times 105 \ldots$

8-10. Cibicides americanus (Cushman), $\times 75$. $8 \mathrm{a}, 9 \mathrm{a}$, Dorsal views; $8 \mathrm{~b}, 9 \mathrm{~b}$, ventral views; $8 \mathrm{c}, 9 \mathrm{c}$, peripheral views

11-13. Cibicides cf. C. lobatulus (Walker and Jacob), $\times 55.11,12$, Dorsal views; 13, ventral view .-

14. Cibicides mississippiensis (Cushman), $\times 80$. a, Dorsal view; $b$, ventral view; $c$, peripheral view $\ldots . . .$.

15, 16. Planorbulina larvata Parker and Jones, $\times 35$ 



\section{N D E X}

A

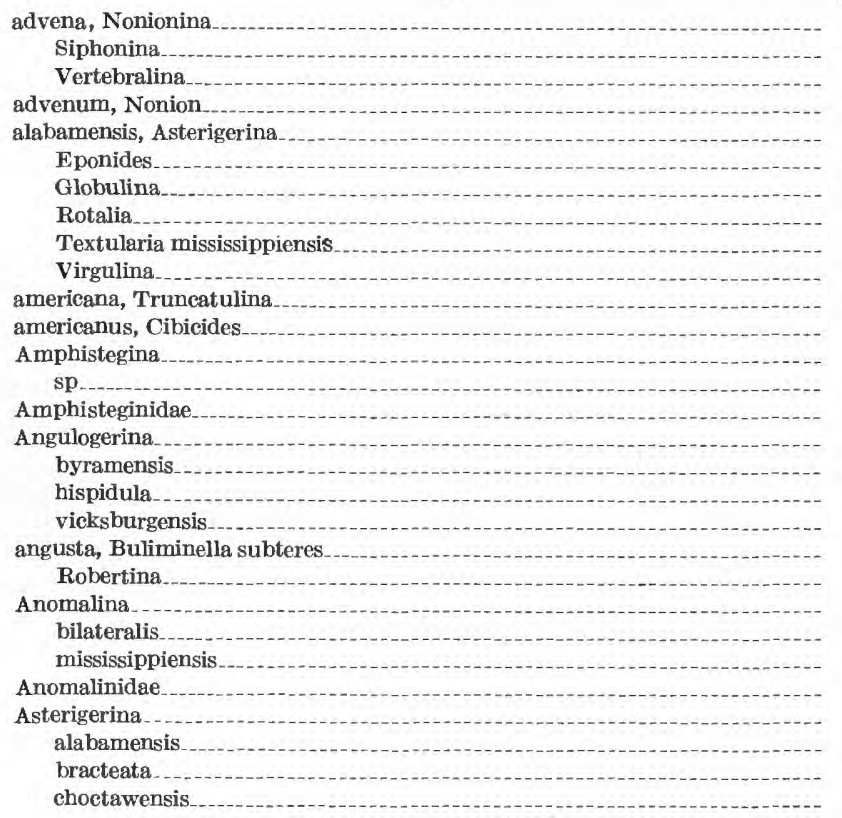

B

Bifarina dalli

bilateralis, Anomalina

Bolivina

byramensis

caelata

byramensis

choctawensis

ef. B. gracilis

cf. B. mexicana

mississippiensis

mornhinvegi.

paula

quadricosta

tortuosa

bracteata, Asterigerina

Buliminella

cf. B. elegantissima, va

subteres, angusta

Buliminidae

byramensis, Angulogerina

Bolivina.

caelata.

Discorbis

Eponides

Pulvinulina

byramensis, Rotalia

Spiroloculina.

Uvigerina

caelata, Bolivina

byramensis, Bolivina.

Cancris.

sagra, pauciloculata

caribaea, Globulina inaequalis

Cassidulina

cf. C. crassa.

cf. C. laevigata

Cassidulinidae.

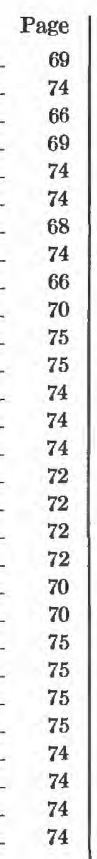

catesbyi, Nodosaria ef. $\mathrm{N}$

choctawensis, Asterigerina

Bolivina.

Eponides.

Cibicides

americanus

ef. C. lobatulus

mississippiensis

Clavulina

ef. C. tricarinata

communis, Dentalina ef. D

crassa, Cassidulina of. $\mathrm{C}$

crumenata, Entosolenia

dalli, Bifarina

Loxostoma ..

danvillensis, Nonionella

decorata, Massilina

decoratum, Nonion

Dentalina.

cf. D. communis

pseudoinvolven

$\mathrm{sp}$

Discorbis.

byramensis.

patelliformis.

subaraucana

subpatelliformis

F

elegantissima, Bulimina of. B. var

Ellipsoidinidae

Ellipsonodosaria

sp.

Elphidium

sp . .

Entosolenia.

crumenata

laevigata

Eponides.

alabamensis

byramensis

choctawensis

F

frondea, Polymorphina

G

gibba, Globulina

glabrata, Lamarckina

Pulvinulina

glabrata, Reussella spinulos

Verneuilina spinulosa

Globulina

alabamensis

gibba

inaequalis. caribaea.

gracilis, Bolivina of. $\mathbf{B}$

Guttulina

cf. G. lehneri

cf. G. problema

Gyroidina.

sp

Heterohelicidae

hispidula, Angulogerina
Page

67

74

75 
I

inaequalis, Globulina

caribaea

L

laevigata, Cassidulina of $\mathrm{C}$ Entosolenia

Lagena.

cf. L. lineata

striata, substriata

cf. L. striato-punetata

sulcata

Lagenidae

Lamarckina

glabrata.

larvata, Planorbulina

$$
\text { vulgaris. }
$$

lehneri, Guttulina of. $\mathrm{O}$

Lepidocyclina

(Eulepidina) cf. L. undosa, var

sp..

lineata, Lagena ef. $\mathbf{L}$

lobatulus, Cibicides ef. C

Loxostoma

dalli

vicksburgense.

Marginulina

$\mathrm{sp}$

Massilina

mexicana, Bolivina ef. $B$

Miliolidae.

mississippiensis, alabamensis, Textularia

Anomalina.

Bolivina

Cibicides

mornhinvegi, Bolivina

$\mathrm{N}$

Nodogenerin

sp.

Nodosaria.

cf. $N$. catesbyi

vertebralis

Nonion.

advenum.

decoratum

Nonionella

danvillensis

oligocenica

Nonionidae.

Nonionina advena

\section{o}

oligocenica, Nonionella

Pyrgo

Ophthalmidiidae

Orbitoididae

patelliformis, Discorbis

paucilocula, Valvulineria

pauciloculata, Cancris sagra

paula, Bolivina

Planorbulina

larvata

vulgaris, larvata

Planorbulinidae.

Pleurostomella vicksburgensis

Polymorphina

frondea

Polymorphinidae

problema, Guttulina ef. $\mathrm{G}$

pseudoinvolvens, Dentalina
Page

68

75

75

70

67

67

8

73
73

75

75

75

75

67

5

1

1

71

7

67 69
9
7
7
9
9
9
9
9
9
6
9

66

66

75

72

73

74

70

75

75

75

75

71

68

68

68
Page

vinuling byramensis glabrata

Pyrgo

oligocenica

\section{Q}

quadricosta, Bolivin

Quinqueloculina

sp ...

tessellata

Reussella

spinulosa, glabrata

Robertina.

angusta

otalia

alabamensis

byramensis

Rotaliidae.

S

sagra, pauciloculata, Cancris

Pulvinulina

sculpturata, Valvulineria

Siphonina.

advena.

spinulosa, glabrata, Reussella

Verneuiline

byramensis

striata, substriata, Lagena

striato-punctata, Lagena cf. I

subaraucana, Discorbis.

subpatelliformis, Discorbis

substriata, Lagena striata

subteres, angusta, Buliminell

sulcata, Lagena

$\mathbf{T}$

tessellata, Quinqueloculin

Textularia

mississippiensis, alabamensis

tumidula -

tumidulum

Textulariidae.

tortuosa, Bolivina

tricarinata, Clavulina cf. $\mathrm{C}$

Truncatulina americana

tumidula, Textularia

turnidulum, Textularia

U

undosa, var. Lepidocyclina (Eulepidina) cf. L

Uvigerina byramensis.

V

Vaginulina

sp

paucilocul

sculpturata

Valvulinidae.

66

Verneuilina spinulosa, glabrata

ertebralina

ertebralis, Nodosaria

vicksburgense, Loxostoma.

vicksburgensis, Angulogerina

Pleurostomella

Virgulina

Virgulina

alabamensis

sp_.

vicksburgensis

vulgaris, larvata, Planorbulina
73

74 